\title{
Self-regulated Learning Skills: Adaptation of Scale*
}

\author{
Şenol ŞEN **
}

Ayhan YILMAZ ***

Ömer GEBAN ****

\begin{abstract}
The aim of this study is to adapt and examine the psychometric properties of Achievement Goal Scale (AGS) originally constructed by Elliot and McGregor (2001) and the Motivated Strategies for Learning Scale (MSLQ) originally constructed by Pintrich, Smith, Garcia and McKeachie (1991) in order to measure the self-regulated learning skills of high school students' in a chemistry course. The study group was comprised of 862 high school students attending a chemistry course in different public schools. The construct validity of the sub-scales included in the scales were tested by confirmatory factor analysis. For the reliability studies, the internal consistency coefficient Cronbach's alpha $(\alpha)$ values as well as McDonald's $\omega$ (omega) coefficients were calculated. In addition, item-total correlations were calculated for the reliability of each item in the scales. When the confirmatory factor analysis results were examined, it was accepted that the fit indices met the goodness of fit criteria for both the Achievement Goal Scale and Motivated Strategies for Learning Scale. Factor loadings of the items in both scales were statistically significant. These results showed that the Turkish forms of both scales have enough psychometric properties in terms of validity and reliability for a chemistry course.
\end{abstract}

Key Words: Adaptation of scale, chemistry, high school, self-regulation.

\section{INTRODUCTION}

Self-regulation is a cyclic process that individuals monitor their own behaviours; make a judgement by comparing based on their own criteria and regulate their behaviours. Self-regulated individuals affect, lead and control their own behaviours (Bandura; as cited in Senemoğlu, 2011). According to Zimmerman (2000) self-regulation is the thoughts, feelings and behaviours which individuals develop to achieve their goals and which emerge cyclically. Social cognitive theory contends that selfregulation develops in social environments and is internalised by individuals through time. According to the theory, self-regulation includes cognitive, metacognitive and motivational components in its structure (Zimmerman; as cited in Sakız \& Yetkin Özdemir, 2014). Therefore, self-regulated students take on metacognitively, motivationally and behaviourally active roles in the process of learning, they set their own learning goals and they control this process (Zimmerman, 1989). Self-regulation is not defined as a mental ability or as an academic skill but rather as a self-directive process in which learners adapt their cognitive competencies in the form of academic abilities (Zimmerman, 2002).

Most of the learning models which have been developed by researchers in the field of education and which are based on self-regulation are based on Zimmerman's (1989) cyclical model. Pintrich's selfregulation model, one of those models, was developed in the context of Social Cognitive Theory. Motivational components play important roles in this model (Pintrich, 1999; 2000a; Pintrich \& DeGroot, 1990; Pintrich et al., 1991; 1993). The feature of this model suggested by Pintrich is that it reflects a social cognitive perspective and that it includes motivational processes; because if students are not motivated to use their cognitive and metacognitive skills, these skills are not important

\footnotetext{
* The present study is a part of PhD Thesis entitled "Investigation of Students' Conceptual Understanding of Electrochemistry and Self-Regulated Learning Skills in Process Oriented Guided Inquiry Learning Environment" completed within Hacettepe University Graduate School of Educational Sciences. This study was supported by Research Fund of Hacettepe University.

** Assoc. Prof. Dr., Hacettepe University, Faculty of Education, Ankara, Turkey, e-mail: schenolschen@ gmail.com, ORCID ID: http://orcid.org/0000-0003-3831-3953

*** Prof. Dr., Hacettepe University, Faculty of Education, Ankara, Turkey, e-mail: ayhany@ hacettepe.edu.tr, ORCID ID: http://orcid.org/0000-0003-4252-5510

**** Prof. Dr., Middle East Technical University, Faculty of Education, Ankara, Turkey, e-mail: geban@metu.edu.tr, ORCID ID: https://orcid.org/0000-0002-9433-0056
}

To cite this article:

Şen,, Ş., Yılmaz, A., \& Geban, Ö. (2018). Self-regulated learning skills: adaptation of scale. Journal of Measurement and Evaluation in Education and Psychology, 9(4), 339-355. DOI: 10.21031/epod.439039 
(McCoach \& Siegle, 2003; Pintrich \& DeGroot, 1990). According to Pintrich (2000a), self-regulation is a process in which learners set goals for themselves, follow them and try to organise their motivation, cognition and behaviours. This process is determined, organised and restricted by learners' goals and by the contextual properties of the environment they are in. Pintrich stresses that self-regulated learning is the learning actualised to develop self-efficacy and states that self-efficacy in addition to motivation is an important component of self-regulation (as cited in Sarı \& Akınoğlu, 2009). Garcia and Pintrich also claim that motivation, an important component of self-regulation, is composed of individuals' beliefs about themselves such as personal goals, self-efficacy and value beliefs in addition to their perceptions about the classroom (as cited in Özturan, Sağırlı, Çiltaş, Azapağası \& Zehir, 2010).

With the emergence of self-regulation models based on social cognitive theory, the notion of the importance of context in self-regulation processes has emerged. Context can be defined as the circumstances creating an environment for a situation, an idea or an event (Context, 2018). With the emergence of the idea that context can influence the validity of findings, measurements were made sensitive to the context. Thus, measurements for different domains of learning gained more and more importance (Pintrich; as cited in Özbay, 2008). Briefly, measurements sensitive to the context and directed to specific areas of learning and specific tasks instead of measurements based on generalisations became more important. Motivated Strategies for Learning Scale (MSLS) developed by Pintrich et. al (1991) is frequently used in the literature. Pintrich et al (1991) chose a course for university students as the unit of analysis in the scale (Özbay, 2008). MSLS was developed on the basis of the view that context had significant effects on the use of motivation and learning strategies and that different strategies should be used in different areas and tasks of learning (Özbay, 2008). MSLS contains five sub-dimensions as the indicators of students' cognitive regulation. They are labelled as rehearsal, elaboration, organisation, critical thinking and metacognitive self-regulation. There are some sub-dimensions on which cognition control activities and monitor measurements in the framework of self-regulated learning model suggested by Pintrich (2000a) and some performance control activities in the framework of the model suggested by Zimmerman (2000) are included. MSLS does not contain sub-dimensions for measuring motivational strategies related to organising motivation and feelings. Yet, there are sub-dimensions such as achievement goals containing performance and mastery, task value, self-efficacy for learning and performance and test anxiety at the forethought stage of Zimmerman's model. In relation to organising behaviours, MSLS includes three sub-dimensions. They are the sub-dimensions of effort regulation, time and study environment management and help seeking. Indeed, two self-regulation models which were developed by Zimmerman and Pintrich and which were based on social cognitive theory lay emphasis on such selfregulation strategies as performance control, time management, help seeking and environmental configuration. Lastly, MSLS contains two more sub-dimensions related to organising the context. They are called peer learning and time and study environment management. They are used to find how well students use their friends as sources of learning and how well they manage their study environment and time (Yumuşak, Sungur, \& Çakıroğlu, 2007).

Achievement goals included in MSLS influence learners' task determination and problem-solving efforts in addition to their study behaviours and recalling. According to Bandura, individuals' setting goals can cause increase in their motivation (as cited in Driscoll, 2005). When individuals set their goals, they evaluate their performance and their level intrinsically and they decide on the basis of extrinsic criteria. If they cannot attain such a standard, they will insist on their efforts. However, all these goals will not maintain this insistence. Goals set should have certain properties for this. Motivated Strategies for Learning Scale has two types of achievement goals labelled as mastery goals and performance goals. Yet, performance goals are divided into two as performance approach and performance avoidance in the literature (Elliot \& Church, 1997; Skaalvik; as cited in Şenler, 2011). In later studies, however, mastery goals are divided into two as mastery approach and mastery avoidance in a similar vein (Elliot, 1999; Pintrich, 2000b). While performance approach goals involve such goals as doing better than others do and being the best, performance avoidance goals involve such goals as avoiding being ordinary. Mastery approach goals aim to learn and understand in depth whereas mastery avoidance goals emphasise not learning and misunderstanding (Elliot \& Church, 1997; Elliot \& McGregor, 2001; Elliot \& Reis, 2003). Therefore, the need for using sub-dimensions for mastery 
goals and performance goals available in MSLS arises. Achievement goal Scale (AGS) can be used in analysing mastery goals in MSLS as mastery approach goals and mastery avoidance goals and performance goals as performance approach goals and performance avoidance goals in four parts. Thus, Achievement Goal Scale has four components: mastery approach goals, performance approach goals, mastery avoidance goals and performance avoidance goals (Elliot \& McGregor, 2001). The other items in the scale are not the items for goal orientation. However, the researchers developing the scale recommend that these items be included and implemented in the scale although they are not used.

\section{Purpose of the Study}

The need for making measurements sensitive to the context emerges since context influences the validity of findings. For this reason, measurements directed to different areas of learning have been gaining more and more importance (Pintrich; as cited in Özbay, 2008). Yet, it was found in studies that there were no reliable and valid scales for determining high school students' self-regulated learning skills in different courses. Therefore, scales are needed for primarily use in assessment so as to develop students' self-regulated learning skills in chemistry course. Besides, the fact that achievement goals available in MSLS are limited to two goals in the literature made it necessary to use MSLS along with AGS. Therefore, the two scales should be adapted and validity and reliability of the scales should be examined. In line with this need, this study adapts MSLS and AGS into chemistry course and analyses the psychometric properties to determine high school students' self-regulated learning skills.

\section{METHOD}

\section{Research model}

This study employs survey model. Survey model is a research approach aiming to describe a situation existed in the past or existing at present as it is. When it is impossible to reach the population, study can be conducted with a small sample taken from the population in survey studies (Fraenkel \& Wallen, 2000).

\section{Participants}

A total of 862 high school students who were the $9^{\text {th }}, 10^{\text {th }}, 11^{\text {th }}$ and $12^{\text {th }}$ graders in differing state schools in Ankara were included in the study. \% 35.03 of the participants were female whereas $33.06 \%$ were male. In addition to that, $31.9 \%$ of the participants did not make any coding for gender. The participants' age ranged between 16 and 20 .

\section{Data Collection Instruments}

\section{Achievement Goal Scale (AGS)}

Achievement Goal Scale (AGS) was developed by Elliot and McGregor (2001) and was adapted into Turkish by Şenler and Sungur (2007). The scale was adapted by Şenler and Sungur (2007) into science course and it was administered to primary school students. The 7-pointed Likert type scale was changed into 5-pointed Likert type. This study, on the other hand, adapts the scale into chemistry course for high school students using 7-pointed Likert type as in the original version by getting permission. The scale was administered to 862 students in total.

The scale has four sub-factors. The factor of mastery approach goals included items 1, 6 and 8; the factor of performance approach goals included items 4, 10 and 16; the factor of mastery avoidance goals included items 11, 14 and 17 and the factor of performance avoidance goals included items 2, 7, 13, 19, 20 and 21 (Elliot \& McGregor, 2001). The other items included in the 21-item scale were not related to goal orientation. Yet, the researchers who had developed the scale recommended that these 
items be included in the scale and be implemented although they were not used. Thus, items 15 and 18 available in the scale were in the factor of competence expectancies (Elliot \& Church, 1997) and items 3, 5, 9 and 12 were in the factor of challenge and threat appraisals (Elliot \& Reis, 2003).

\section{Motivated Strategies for Learning Scale (MSLS)}

Motivated Strategies for Learning Scale (MSLS) was developed by Pintrich, Smith and McKeachie (1991) so as to be informed of university students' motivation in classes and of the learning strategies they used in those classes. The scale was adapted into Turkish by Büyüköztürk, Akgün, Özkahveci and Demirel (2004) and Sungur (2004). It is a 7-pointed Likert type scale. It has two main components called motivation and learning strategies. The motivation component is composed of six sub-factors. These are intrinsic goal orientation, extrinsic goal orientation, task value, control of learning beliefs, self-efficacy for learning and performance and text anxiety. The learning strategies part is related to different cognitive and metacognitive strategies students use and contains 31 items. In addition to the 31 items, there are also 19 items related to different resource management strategies. Learning strategies part includes nine sub-factors labelled as rehearsal, organization, elaboration, critical thinking, metacognitive self-regulation, time and study environment, effort regulation, peer learning and help seeking. High scores received from any factor in MSLS indicate that students have high levels of the property related to the factor (Pintrich et al., 1991; Büyüköztürk et al., 2004). Having received the necessary permission, the scale was adapted for use with chemistry course with high school students, and thus it was administered to 862 students.

\section{Data Analysis}

Prior to analyzing the data, the items which were stated negatively in the original version of the scale were coded inversely. First order confirmatory factor analysis was conducted for construct validity to see whether or not Achievement goal scale and Motivated Strategies for Learning Scale measured the intended structure. Because factor loadings were not equal, both Cronbach's alpha $(\alpha)$ and McDonald Omega $(\alpha)$ reliability coefficients were calculated so as to determine reliability in the sense of internal consistency. In this study, LISREL software was used for confirmatory factor analysis and SPSS and Excel software packages were used for reliability analyses.

\section{Language Validity}

Turkish adaptations of MSLS from English made earlier (Büyüköztürk et al. 2004; Sungur, 2004; Taştan, 2009; Yalçınkaya, 2010) and AQS study in Turkey (Şenler and Sungur) were examined in this study and expert opinion was consulted for the translated items which were determined. Efforts were made to see whether or not the translated items were equivalent to the original items and to see the degree to which the items in the Turkish version were compatible with Turkish grammar and were intelligible. After expert opinion was obtained, modifications were made, the resultant form was administered to a group of high school students having similarities with the students with whom the application would be done. The items of the revised version were checked in terms of content, and the language of the form was modified based on students' feedback.

\section{RESULTS}

This section presents the findings obtained from the analyses done for validity and reliability of both scales. The results for confirmatory factor analysis conducted for structure validity of the scales are shown in Table 1. 
Table 1. The Fit Indices for the Achievement Goal Scale

\begin{tabular}{llllllllll}
\hline $\mathrm{N}$ & $\begin{array}{l}\chi^{2} / \mathrm{df} \\
(<3.0)\end{array}$ & $\begin{array}{l}\text { RMSEA } \\
(<.08)\end{array}$ & $\begin{array}{l}\text { CFI } \\
(>.95)\end{array}$ & $\begin{array}{l}\text { IFI } \\
(>.90)\end{array}$ & $\begin{array}{l}\text { GFI } \\
(>.90)\end{array}$ & $\begin{array}{l}\text { NFI } \\
(>.90)\end{array}$ & $\begin{array}{l}\text { AGFI } \\
(>.85)\end{array}$ & $\begin{array}{l}\text { NNFI } \\
(>.95)\end{array}$ & $\begin{array}{l}\text { SRMR } \\
(<.1)\end{array}$ \\
\hline 862 & 5.26 & .070 & .98 & .98 & .94 & .97 & .91 & .97 & .042 \\
\hline
\end{tabular}

When the fit indices of the Achievement Goal Scale were examined in Table 1 and Figure 1, it was concluded that the values apart from Chi square/df (5.26)- which were fit indices- met the criterion for good fit $\left(\chi^{2} / \mathrm{df}<3.0\right.$; RMSEA <.08; CFI $>.95$; IFI >.90; GFI $>.90 ;$ NFI >.90; AGFI >.85; NNFI >.95; SRMR <.1) (Çelik \& Y1lmaz, 2013; Schermelleh-Engel, Moosbrugger, \& Müller, 2003).

Table 2. Reliability Analysis Results for the Achievement Goal Scale

\begin{tabular}{|c|c|c|c|c|c|c|c|c|}
\hline Subscales & Item No & $\lambda x$ & $\delta$ & $\mathrm{t}$ & $\mathrm{R}^{2}$ & $\begin{array}{l}\text { Item } \\
\text { Total } \\
\text { Cor. }\end{array}$ & $\alpha$ & $\omega$ \\
\hline \multirow{3}{*}{ Mastery approach goals } & $\mathrm{m} 1$ & .74 & .46 & 24.24 & .55 & .67 & \multirow{3}{*}{.85} & \multirow{3}{*}{.84} \\
\hline & $\mathrm{m} 6$ & .84 & .29 & 29.48 & .71 & .71 & & \\
\hline & $\mathrm{m} 8$ & .84 & .29 & 29.45 & .71 & .70 & & \\
\hline \multirow{3}{*}{ Mastery avoidance goals } & $\mathrm{m} 11$ & .72 & .47 & 23.60 & .52 & .64 & \multirow{3}{*}{.79} & \multirow{3}{*}{.79} \\
\hline & $\mathrm{m} 14$ & .87 & .24 & 3.55 & .76 & .77 & & \\
\hline & $\mathrm{m} 17$ & .64 & .59 & 2.03 & .41 & .59 & & \\
\hline \multirow{3}{*}{ Performance approach goals } & $\mathrm{m} 4$ & .84 & .29 & 29.30 & .71 & .77 & \multirow{3}{*}{.77} & \multirow{3}{*}{.78} \\
\hline & $\mathrm{m} 10$ & .80 & .36 & 27.44 & .64 & .73 & & \\
\hline & $\mathrm{m} 16$ & .55 & .70 & 16.61 & .30 & .51 & & \\
\hline \multirow{6}{*}{ Performance avoidance goals } & $\mathrm{m} 2$ & .38 & .86 & 1.85 & .14 & .36 & \multirow{6}{*}{.67} & \multirow{6}{*}{.67} \\
\hline & $\mathrm{m} 7$ & .48 & .77 & 14.08 & .23 & .45 & & \\
\hline & $\mathrm{m} 13$ & .69 & .53 & 21.70 & .48 & .61 & & \\
\hline & $\mathrm{m} 19$ & .71 & .50 & 22.49 & .50 & .67 & & \\
\hline & $\mathrm{m} 20$ & .22 & .95 & 6.32 & .05 & .22 & & \\
\hline & $\mathrm{m} 21$ & .49 & .76 & 14.59 & .24 & .46 & & \\
\hline
\end{tabular}

Figure 1 and Table 2 show the variance values described with $t$ values which were found to be significant for each item, the factor loadings $(\lambda x)$ and error variances $(\delta)$. Accordingly, it was found that factor loadings in the sub-factors were found to range between .22 and .87 . to perform the reliability analysis for the scale, McDonald's coefficient (omega)- which is recommended when the factors loading in each factor were not equal- in addition to Cronbach's alpha values was also found (Zinbarg, Revelle, Yovel \& Li, 2005). Cronbach's alpha reliability coefficients were found to range between .67 and .85 . In addition to reliability analyses, total item correlation suggesting the consistency of each item with the whole factor in which the item belonged was also analysed. It was found in consequence that only the total correlation for item 20 was smaller than .30 yet, some studies in the literature (Briggs \& Cheek, 1986, for instance) point out that item correlation coefficient in .15.50 interval would be sufficient for scales measuring more comprehensive properties. Clark and Watson (1995), on the other hand, state that the values between .15 and .20 would be adequate for total item correlation in scales measuring more comprehensive properties. Since AGS measured the different properties of both mastery and performance, decision was made to include this item in the study. 


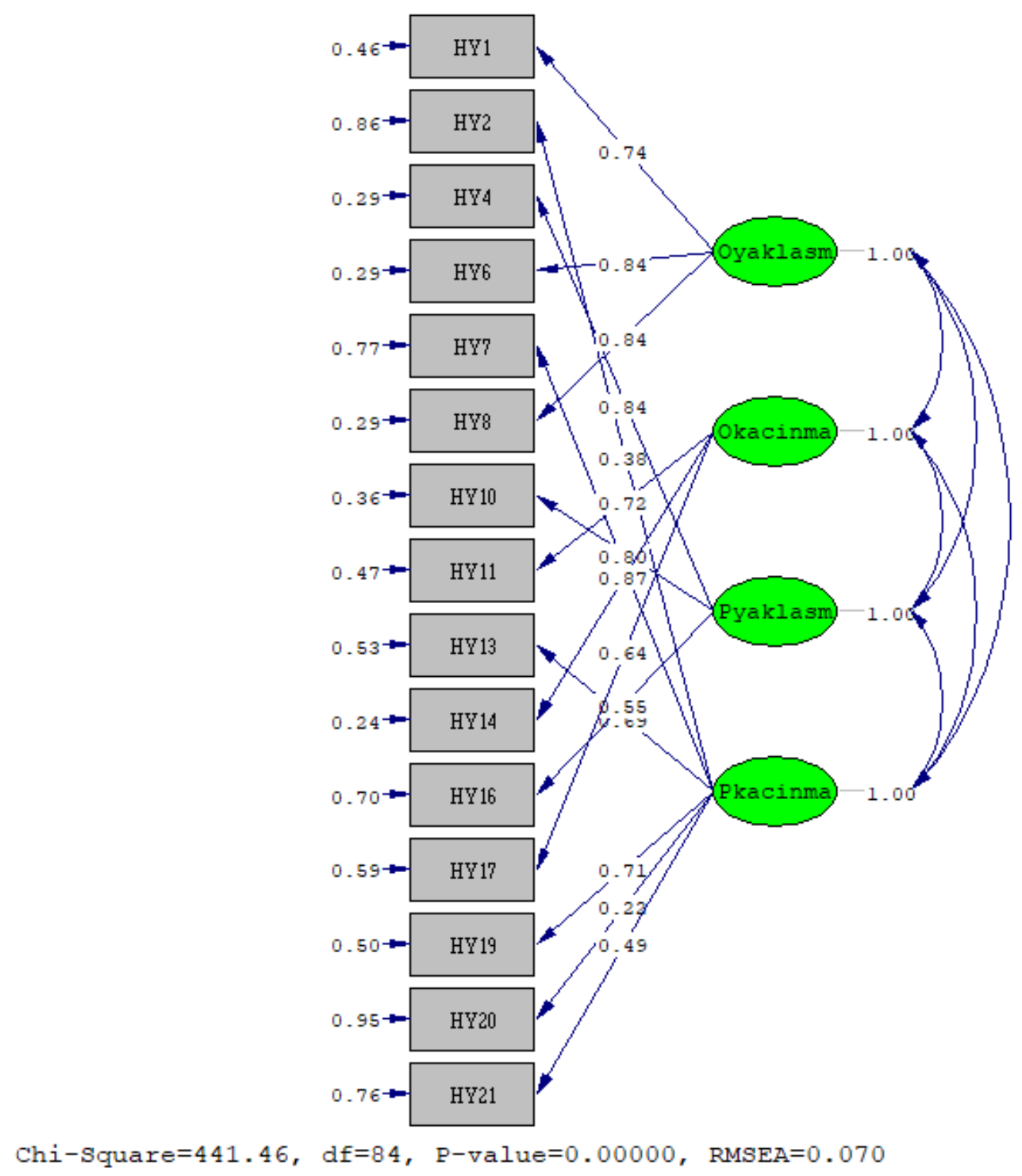

Figure 1. Path Diagram and Factor Loadings for the Achievement Goal Scale

Table 3. The Fit Indices for MSLS Motivation Section

\begin{tabular}{llllllllll}
\hline $\mathrm{N}$ & $\begin{array}{l}\chi^{2} / \mathrm{df} \\
(<3.0)\end{array}$ & $\begin{array}{l}\text { RMSEA } \\
(<.08)\end{array}$ & $\begin{array}{l}\text { GFI } \\
(>.90)\end{array}$ & $\begin{array}{l}\text { NNFI } \\
(>.95)\end{array}$ & $\begin{array}{l}\text { NFI } \\
(>.90)\end{array}$ & $\begin{array}{l}\text { CFI } \\
(>.95)\end{array}$ & $\begin{array}{l}\text { AGFI } \\
(>.85)\end{array}$ & $\begin{array}{l}\text { IFI } \\
(>.90)\end{array}$ & $\begin{array}{l}\text { SRMR } \\
(<.1)\end{array}$ \\
\hline 862 & 5.22 & .070 & .89 & .97 & .97 & .97 & .87 & .97 & .044 \\
\hline
\end{tabular}

Following the confirmatory factor analysis conducted for the motivation section of Motivated Strategies for Learning Scale, it was concluded that the values apart from Chi square/df (5.22)- which were fit indices- met the criterion for good fit (See Table 3 and Figure 2). $\left(\chi^{2} / \mathrm{df}<3.0\right.$; RMSEA $<.08$; CFI >.95; IFI >.90; GFI >.90; NFI >.90; AGFI >.85; NNFI >.95; SRMR <.1) (Çelik \& Y1lmaz, 2013; Schermelleh-Engel, Moosbrugger, \& Müller, 2003). 
Table 4. Reliability Analysis Results for MSLS Motivation Section

\begin{tabular}{|c|c|c|c|c|c|c|c|c|}
\hline Subscales & Item No & $\lambda x$ & $\delta$ & $\mathrm{t}$ & $\mathrm{R}^{2}$ & $\begin{array}{l}\text { Item } \\
\text { Total } \\
\text { Cor. }\end{array}$ & $\alpha$ & $\omega$ \\
\hline \multirow[t]{6}{*}{ Task Value } & 4 & .58 & .67 & 17.80 & .34 & .55 & \multirow{6}{*}{.85} & \multirow{6}{*}{.85} \\
\hline & 10 & .68 & .53 & 21.99 & .46 & .65 & & \\
\hline & 17 & .67 & .55 & 21.58 & .45 & .62 & & \\
\hline & 23 & .79 & .38 & 26.98 & .62 & .72 & & \\
\hline & 26 & .71 & .50 & 23.12 & .50 & .65 & & \\
\hline & 27 & .77 & .40 & 26.08 & .59 & .71 & & \\
\hline \multirow[t]{4}{*}{ Control of Learning Beliefs } & 2 & .67 & .55 & 21.41 & .45 & .63 & \multirow{4}{*}{.73} & \multirow{4}{*}{.73} \\
\hline & 9 & .47 & .78 & 13.90 & .22 & .46 & & \\
\hline & 18 & .80 & .37 & 26.67 & .64 & .73 & & \\
\hline & 25 & .59 & .65 & 18.17 & .35 & .56 & & \\
\hline \multirow{8}{*}{$\begin{array}{llll}\text { Self-efficacy } & \text { for } & \text { Learning } & \text { and } \\
\text { Performance } & & & \end{array}$} & 5 & .53 & .72 & 16.20 & .28 & .51 & \multirow{8}{*}{.87} & \multirow{8}{*}{.87} \\
\hline & 6 & .52 & .73 & 15.74 & .27 & .50 & & \\
\hline & 12 & .64 & .59 & 2.53 & .41 & .61 & & \\
\hline & 15 & .62 & .61 & 19.66 & .38 & .57 & & \\
\hline & 20 & .77 & .41 & 26.04 & .59 & .71 & & \\
\hline & 21 & .80 & .36 & 27.56 & .64 & .73 & & \\
\hline & 29 & .75 & .43 & 25.31 & .56 & .71 & & \\
\hline & 31 & .78 & .40 & 26.56 & .61 & .74 & & \\
\hline \multirow[t]{5}{*}{ Text Anxiety } & 3 & .42 & .83 & 12.10 & .18 & .40 & \multirow{5}{*}{.61} & \multirow{5}{*}{.60} \\
\hline & 8 & .37 & .86 & 1.75 & .14 & .35 & & \\
\hline & 14 & .65 & .58 & 19.64 & .42 & .58 & & \\
\hline & 19 & .59 & .65 & 17.71 & .35 & .56 & & \\
\hline & 28 & .37 & .86 & 1.62 & .14 & .35 & & \\
\hline
\end{tabular}

Figure 2 and Table 4 show the variance values described with $t$ values which were found to be significant for each item, the factor loadings $(\lambda \mathrm{x})$ and error variances $(\delta)$. Accordingly, it was found that factor loadings in the sub-factors were found to range between .37 and .80 . Cronbach's alpha reliability coefficients were found to range between .61 and .87 .

Table 5. Fit Indices for MSLS Learning Strategies Section

\begin{tabular}{llllllllll}
\hline $\mathrm{N}$ & $\chi^{2} / \mathrm{df}$ & RMSEA & GFI & NFI & CFI & IFI & AGFI & NNFI & SRMR \\
\hline 862 & 3.99 & 0.059 & .83 & .94 & .95 & .95 & .81 & .95 & .079 \\
\hline
\end{tabular}

Following the confirmatory factor analysis conducted for the learning strategies section of Motivated Strategies for Learning Scale, it was concluded that the values apart from $\chi^{2} / \mathrm{df}$ (3.99), GFI (.83) and AGFI (.81) - which were fit indices- met the criterion for good fit. (See Table 5 and Figure 3). $\chi^{2} / \mathrm{df}$ (3.99), GFI (.83) and AGFI (.81) (Table 5 and Figure 3). $\left(\chi^{2} / \mathrm{df}<3.0\right.$; RMSEA <.08; CFI $>95$; IFI > .90; GFI $>$.90; NFI > .90; AGFI >.85; NNFI >.95; SRMR <.1).

Figure 3 and Table 6 show the variance values described with $t$ values which were found to be significant for each item, the factor loadings $(\lambda x)$ and error variances $(\delta)$ for MSLS learning strategies section. Accordingly, it was found that factor loadings in the sub-factors were found to range between .22 and .74. Cronbach's alpha reliability coefficients were found to range between .59 and .84 . 


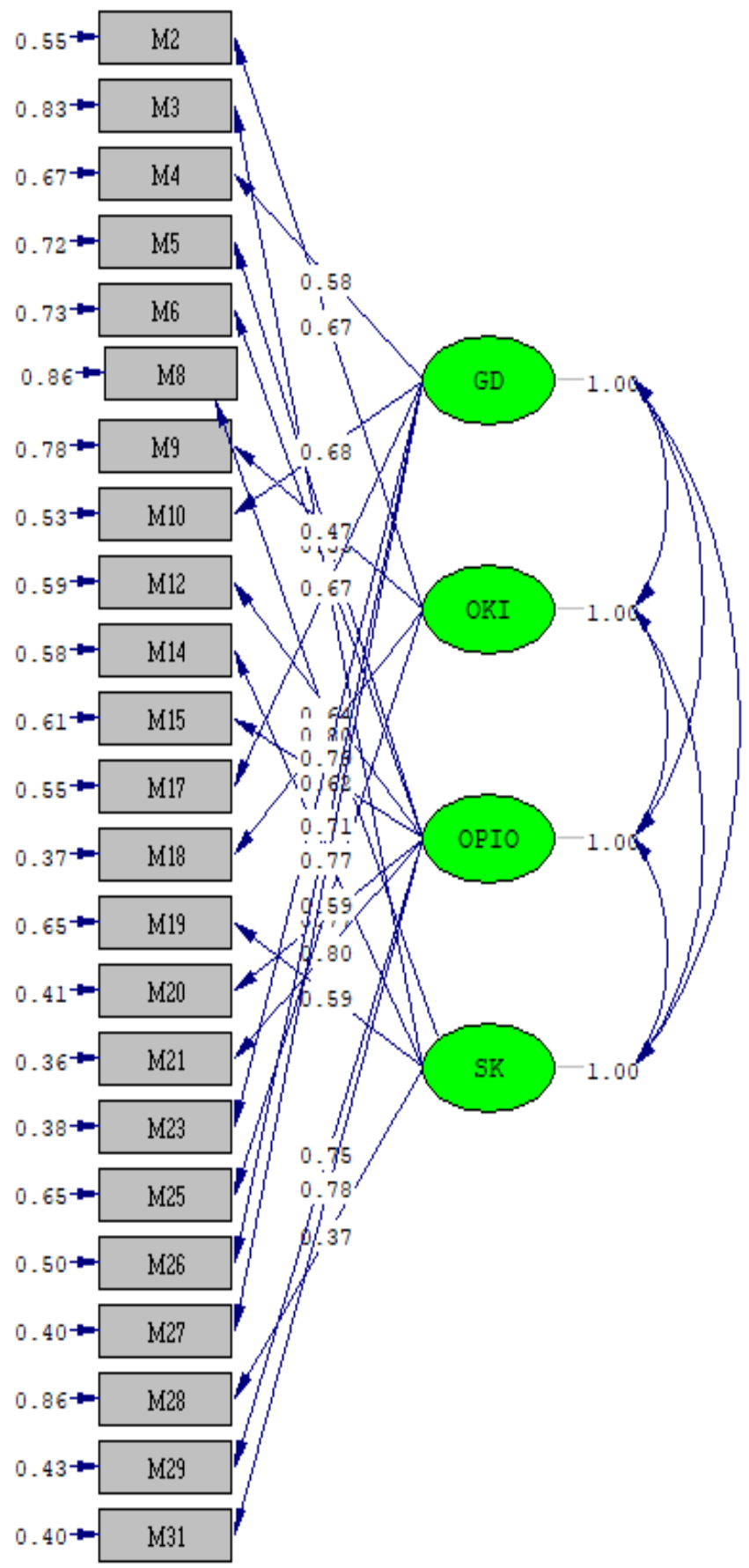

Chi-Square=1169.32, df=224, P-value=0.00000, RMSEA=0.070

Figure 2. Path Diagram and Factor Loadings for MSLS Motivation Section 
Table 6. Reliability Analysis Results for MSLS Learning Strategies Section

\begin{tabular}{|c|c|c|c|c|c|c|c|c|}
\hline Subscales & Item No & $\lambda x$ & $\delta$ & $\mathrm{t}$ & $\mathrm{R}^{2}$ & Item Total Cor. & $\alpha$ & $\omega$ \\
\hline \multirow[t]{4}{*}{ Rehearsal } & 39 & .67 & .55 & 21.41 & .45 & .50 & \multirow{4}{*}{.76} & \multirow{4}{*}{.76} \\
\hline & 46 & .71 & .49 & 23.31 & .50 & .53 & & \\
\hline & 59 & .66 & .56 & 21.24 & .44 & .57 & & \\
\hline & 72 & .62 & .62 & 19.35 & .38 & .53 & & \\
\hline \multirow[t]{4}{*}{ Organization } & 32 & .59 & .65 & 16.21 & .35 & .34 & \multirow{4}{*}{.68} & \multirow{4}{*}{.68} \\
\hline & 42 & .65 & .57 & 18.23 & .42 & .43 & & \\
\hline & 49 & .56 & .69 & 15.25 & .31 & .46 & & \\
\hline & 63 & .56 & .69 & 15.15 & .31 & .39 & & \\
\hline \multirow[t]{6}{*}{ Elaboration } & 53 & .69 & .53 & 22.10 & .48 & .57 & \multirow{6}{*}{.78} & \multirow{6}{*}{.78} \\
\hline & 62 & .67 & .55 & 21.49 & .45 & .57 & & \\
\hline & 64 & .55 & .69 & 16.96 & .30 & .44 & & \\
\hline & 67 & .70 & .52 & 22.56 & .49 & .51 & & \\
\hline & 69 & .74 & .45 & 24.68 & .55 & .55 & & \\
\hline & 81 & .29 & .92 & 8.26 & .08 & .24 & & \\
\hline \multirow[t]{5}{*}{ Critical Thinking } & 38 & .49 & .76 & 14.42 & .24 & .42 & \multirow{5}{*}{.76} & \multirow{5}{*}{.76} \\
\hline & 47 & .64 & .59 & 19.62 & .41 & .52 & & \\
\hline & 51 & .64 & .59 & 19.79 & .41 & .50 & & \\
\hline & 66 & .68 & .54 & 21.20 & .46 & .51 & & \\
\hline & 71 & .66 & .56 & 2.67 & .44 & .48 & & \\
\hline \multirow[t]{4}{*}{ Help Seeking } & 40 & .22 & .95 & 5.80 & .05 & .38 & \multirow{4}{*}{.59} & \multirow{4}{*}{.59} \\
\hline & 58 & .65 & .58 & 18.07 & .42 & .28 & & \\
\hline & 68 & .60 & .65 & 16.53 & .36 & .27 & & \\
\hline & 75 & .57 & .67 & 15.84 & .32 & .18 & & \\
\hline \multirow[t]{3}{*}{ Peer Learning } & 34 & .66 & .56 & 21.31 & .44 & .53 & \multirow{3}{*}{.71} & \multirow{3}{*}{.71} \\
\hline & 45 & .65 & .58 & 2.63 & .42 & .49 & & \\
\hline & 50 & .69 & .52 & 22.37 & .48 & .57 & & \\
\hline \multirow{12}{*}{$\begin{array}{l}\text { Metacognitive } \\
\text { regulation }\end{array}$} & 33 & .25 & .94 & 7.11 & .06 & .43 & & \\
\hline & 36 & .62 & .61 & 19.43 & .38 & .47 & & \\
\hline & 41 & .56 & .68 & 17.19 & .31 & .42 & & \\
\hline & 44 & .57 & .67 & 17.54 & .32 & .47 & & \\
\hline & 54 & .59 & .65 & 18.34 & .35 & .46 & & \\
\hline & 55 & .65 & .58 & 2.55 & .42 & .45 & o & \\
\hline & 56 & .59 & .65 & 18.34 & .35 & .40 & .84 & .85 \\
\hline & 57 & .30 & .91 & 8.54 & .09 & .45 & & \\
\hline & 61 & .57 & .68 & 17.24 & .32 & .52 & & \\
\hline & 76 & .69 & .53 & 22.13 & .48 & .46 & & \\
\hline & 78 & .69 & .52 & 22.38 & .48 & .59 & & \\
\hline & 79 & .66 & .57 & 2.80 & .44 & .32 & & \\
\hline Effort Regulation & 37 & .59 & .65 & 16.46 & .35 & .39 & & \\
\hline & 48 & .65 & .58 & 18.50 & .42 & .09 & 69 & 69 \\
\hline & 60 & .56 & .68 & 15.71 & .31 & .13 & .09 & .09 \\
\hline & 74 & .57 & .67 & 15.94 & .32 & .12 & & \\
\hline Time and Study Environment & 35 & .67 & .55 & 21.67 & .45 & .50 & & \\
\hline & 43 & .60 & .65 & 18.66 & .36 & .53 & & \\
\hline & 52 & .33 & .89 & 9.59 & .11 & .57 & & \\
\hline & 65 & .55 & .70 & 16.90 & .30 & .53 & 75 & 76 \\
\hline & 70 & .59 & .65 & 18.57 & .35 & .34 & .15 & .10 \\
\hline & 73 & .53 & .72 & 16.36 & .28 & .43 & & \\
\hline & 77 & .69 & .52 & 22.66 & .48 & .46 & & \\
\hline & 80 & .27 & .93 & 7.79 & .07 & .39 & & \\
\hline
\end{tabular}




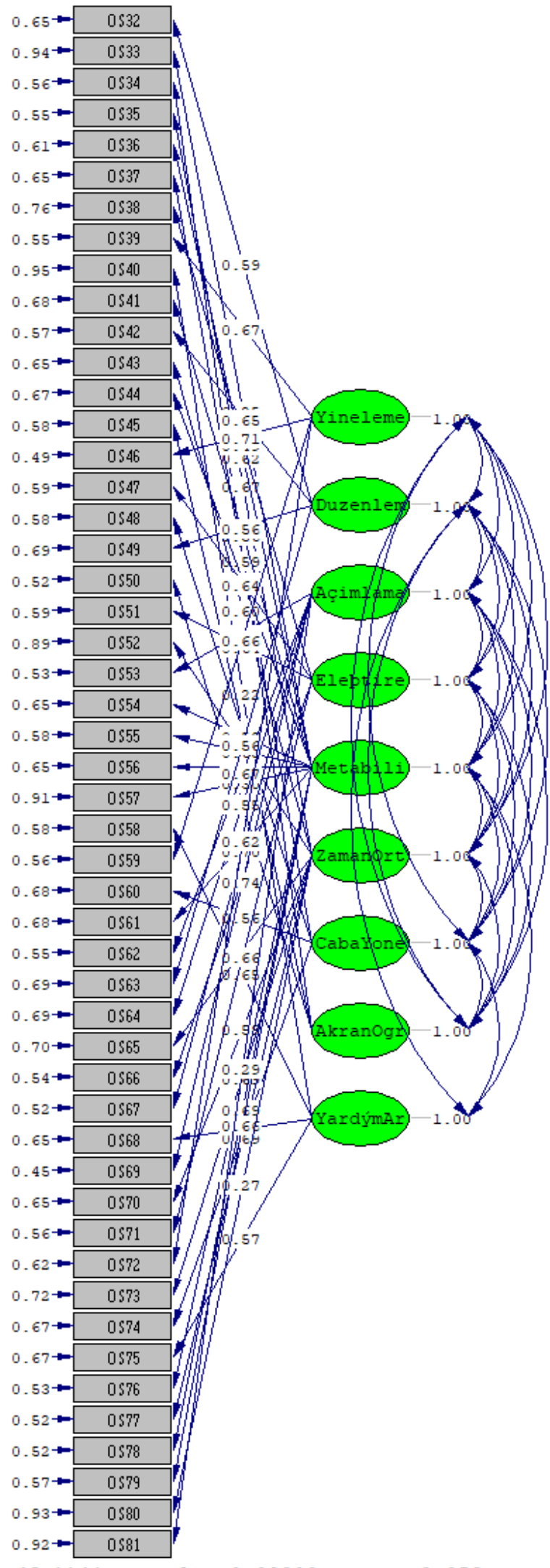

Chi-Square $=4561.96, d f=1144, \mathrm{P}-\mathrm{value}=0.00000, \mathrm{RMSEA}=0.059$

Figure 3. Path Diagram and Factor Loadings for MSLS Learning Strategies Section 


\section{DISCUSSION and CONCLUSION}

Students' individual differences are the properties that should be taken into consideration in teachinglearning process. This is because the teaching-learning approaches students choose and their responses to teaching change according to the difference in their individual properties. Their individual properties can be divided into cognitive, affective, social and physiological categories. Several factors which can be described as individual differences such as having different levels of motivation, difference in perceptual preferences, intelligence level and psychological factors are influential in individuals' teaching-learning processes (Kuzgun-Deryakulu, 2004). One of those individual differences is students' self-regulated learning skills. Therefore, the validity and reliability of the scales were deemed adequate to reveal students' self-regulated learning skills in teaching-learning environments. The emergence of the view that the importance of contexts in self-regulation processes could not be ignored with the arise of self-regulation models based on social cognitive theory made us feel the necessity for scales which could be used with differing courses. For this reason, this study adapted Achievement Goal Scale and Motivated strategies for Learning Scale for chemistry course and analysed the psychometric properties so as to measure high school students' self-regulated learning skills. The sub-factors in the scales were analysed by means of confirmatory factor analysis. In addition to Cronbach's alpha- which was an internal consistency coefficient- McDonald's Omega coefficient was also calculated. Moreover, total item correlations were also analysed for the reliability of each item in the scales.

On examining the results for confirmatory factor analysis performed for Achievement goal Scale, the fit indices for the scale were found as RMSEA= .07; GFI=.94; NFI= .97; AGFI=.91, NNFI=.97; CFI= .98 and SRMR=.042. An examination of fit indices makes it clear that only chi-square/df ratio is below 3. Yet, on considering the other fit indices, it can be concluded that there is good fit. Garver and Mentzer (1999) state that NNFI, CFI and RMSEA can be used in determining model-data fit. Considering the acceptability of RMSEA below 0.8 and having RMSEA of 0.7 in this study along with the other fit indices, it was regarded that the model had good fit (Schermelleh-Engel, Moosbrugger, \& Müller, 2003). Besides, due to the fact that NNFI and CFI (>.90) had acceptable values in this study, the scale was assumed to have construct validity. It can be said that the fit indices obtained in this study yields results similar to the ones in the original scale and the ones in other adaptations. On examining the results of confirmatory factor analysis performed for Achievement Goal Scale developed by Elliot and McGregor (2001), it was found that Chi-square (48, N=148) = 60.49, $\mathrm{p}=.11$; RMSEA $=.042$, Tucker-Lewis Index $(\mathrm{TLI})=.99$ and CFI $=.99$. Another adaptation made by Pamuk (2014) found, on examining the results of confirmatory factor analysis performed for each subfactor, that fit indices were perfect for three sub-factors apart from the sub-factor of performance avoidance. The fit indices for performance avoidance was reported as Chi-square/df $=22.55, \mathrm{NFI}=.97$, $\mathrm{CFI}=.97, \mathrm{SRMR}=.04$ and $\mathrm{GFI}=.98$.

The results of reliability analyses done for Achievement Goal Scale indicated that the Cronbach's Alpha $(\alpha)$ found for mastery approach was .85, it was .79 for mastery avoidance, .77 for performance approach and .67 for performance avoidance. Nunnally (1978) suggested that reliability coefficient be .70 as a general rule. But O'Rourke, Hatcher and Stepanski (2005) pointed out that values below .70 were also adequate and that social scientists even reported values below 60 occasionally (for example Dekovic, Janssens \& Gerris, 1991; Holden, Fekken \& Cotton, 1991). Therefore, when considered along with all other results for the scale, it was concluded that the factors of the scale satisfied the reliability criteria. Additionally, it was found that the other adaptations of this scale made in Turkey had also calculated similar reliability indices. Cronbach's Alpha- which was the internal consistency coefficient- calculated for Achievement Goal Scale developed by Elliot and McGregor (2001) ranged between .83 and .87. Şenler and Sungur (2007), on the other hand, found that Cronbach's Alpha took on values between .64 and .84. Cronbach's Alpha coefficients ranged between .65 and .76 in Pamuk (2014). Examining the results for the scale and the adaptations made in Turkey, it can be said that achievement objectives, a component of self-regulated learning skills, can be measured more comprehensively with this scale (Şen, 2015). 
The fit indices for the motivation part of Motivated Strategies for Learning Scale (MSLS) were found as RMSEA = .07; GFI=.89; NFI= .97; $\mathrm{AGFI}=.87$, NNFI=.97; $\mathrm{CFI}=.97$ and $\mathrm{SRMR}=.044$. On examining the adaptations in the literature and the original version, it can be said that the fit indices found in this study are higher. The results of confirmatory factor analysis conducted for the motivation part of the scale developed by Pintrich et al (1991) were found as Chi square/sd = 3.49; RMR=.07; GFI=.77. In an adaptation made by Sungur (2004) the results for the motivation part were as in the following: Chi-square/sd $=5.3, \mathrm{GFI}=.77$, and RMR $=.11$. Adaptation made by Büyüköztürk et al (2004), however, reported results for the motivation part as: Chi-square/sd $=4.47$, RMSEA=.06, $\mathrm{GFI}=.88, \mathrm{AGFI}=.85, \mathrm{CFI}=.82, \mathrm{NNFI}=.80, \mathrm{RMR}=.18$ and $\mathrm{SRMR}=.06$. It was found that the fit indices for the motivation part of the model in the scale prepared by Pintrich et al (1991) and the fit indices of the adaptations made in Turkey did not have enough model-data fit. Considering the adaptations made by Büyüköztürk et al. (2004), Sungur (2004), Taştan (2009) and Yalçınkaya (20109 and the fit indices for the original version of the scale, it was regarded that the motivation part met the criteria for fit indices. Besides, Pintrich et al (1991) stated that motivational attitudes could change according to the properties of a course, teachers' demands and students' individual properties although the fit indices they had obtained were not within the desired interval; and they claimed that the values they had found were adequate.

In consequence of the reliability analyses performed for MSLS, the Cronbach's Alpha was found as .85 , it was found as .73 for the factor of control of learning beliefs, .87 for the factor of self-efficacy for learning and performance and .61 for the factor of test anxiety. On reviewing the adaptations and original versions in the literature, this study can be said to have higher reliability indices. Only the reliability coefficient found for test anxiety was below .70 in this study. But because O'Rourke, Hatcher and Stepanski (2005) state that the values below .70 are also adequate; it was regarded that Cronbach's Alpha- which was calculated for the sub-factors of the motivation part of MSLS and which was also an internal consistency coefficient, McDonald's omega coefficients and total item correlations met the criteria for reliability. Cronbach's Alpha values found for MSLS following the reliability analyses reported in the literature were found as .62-.93 by Pintrich et al (1991), as .54-.89 by Sungur (2004) and as .52-.86 by Büyüköztürk et al (2004).

The fit indices found for the learning strategies part of MSLS were as in the following: RMSEA=.059; $\mathrm{NFI}=.94 ; \mathrm{GFI}=.83 ; \mathrm{NNFI}=.95 ; \mathrm{AGFI}=.81, \mathrm{CFI}=.95$ and $\mathrm{SRMR}=.079$. Reviewing the adaptations in the literature and the original version, it can be said that the fit indices found in this study are higher. The results of confirmatory factor analysis conducted for the learning strategies part of the scale developed by Pintrich et al (1991) were as in the following: Chi-square/sd = 2.26; RMR=.08; GFI=.78. Sungur (2004) found the values in an adaptation for biology course as: Chi-square/sd $=4.5, \mathrm{GFI}=.71$, and RMR $=.08$. Büyüköztürk et al (2004) found the fit indices for the learning strategies part as: Chisquare/sd = 4.73, GFI=.80, AGFI=.77, CFI=.70 NNFI=.67 RMR=.22, SRMR=.06 and RMSEA=.07.It was found that the fit indices in the adaptation made in Turkey did not meet the model-data fit values as in the fit indices for the learning strategies part of the model in the scale prepared by Pintrich et al (1991). Considering the original scale and the fit indices of the adaptations in Turkey, it was regarded that the fit indices for the scale met the indices for good fit. Besides, Pintrich et al (1991) state that students' use of strategies differs according to students' individual differences, teachers' properties and the structure of courses; and that therefore researchers consider the values they find as acceptable. For this reason, considering the adaptations made for MSLS (Büyüköztürk et al., 2004; Pintrich et al., 1991, Sungur, 2004) it may be said that the reliability indices found are acceptable.

Cronbach's Alpha found for the factor of rehearsal of MSLS was .76, it was .68 for the factor of organisation, .78 for the factor of elaboration, .76 for the factor of critical thinking, .84 for the factor of metacognitive self-regulation, .75 for the factor of time and study environment, .69 for the factor of effort regulation, .71 for the factor of peer learning and .59 for the factor of help seeking (Şen, 2015). On examining the adaptations in the literature and the original version, it can be stated that the reliability indices found in this study are higher. Cronbach's Alpha was found as .52-.80 by Pintrich et al (1991), as .57-.81 by Sungur (2004) and as .41-.75 by Büyüköztürk et al (2004). On examining the Cronbach's alpha values, McDonald's Omega coefficients and total item correlations, it was regarded 
that the sub-factors in the learning strategies part of the scale met the criteria for reliability. Considering all the figures for the questionnaire it was concluded that the questionnaires had met the reliability criteria. In consequence, having done validity and reliability analyses, both questionnaires can contribute to the literature as questionnaires which are capable of serving to the purpose of determining self-regulated learning skills. Besides, educators can also analyse the results by using each sub-factor available in the questionnaires separately.

\section{REFERENCES}

Briggs, S. R., \& Cheek, J. M. (1986). The role of factor analysis in the development and evaluation of personality scales. Journal of Personality, 54, 106-148. doi: 10.1111/j.1467-6494.1986.tb00391.x

Büyüköztürk, Ş., Akgün, Ö. E., Demirel, F. ve Özkahveci, Ö. (2004). Güdülenme ve Öğrenme Stratejileri Ölçeği'nin Türkçe formunun geçerlik ve güvenirlik çalışması. Kuram ve Uygulamada Eğitim Bilimleri, 4(2), 207-239.

Clark, L. A., \& Watson, D. (1995). Constructing validity: Basic issues in objective scale development. Psychological Assessment, 7(3), 309-319.

Context. (2018). In Oxford dictionaries, Retrieved from https://en.oxforddictionaries.com/definition/context.

Çelik, H. E. ve Yılmaz, V. (2013). Lisrel 9.1 ile yapısal eşitlik modellemesi (Yenilenmiş 2. Baskı). Ankara: Anı Yayıncılık.

Dekovic, M., Janssens, J. M. A. M., \& Gerris, J. R. M. (1991). Factor structure and construct validity of the Block Child Rearing Practices Report (CRPR). Psychological Assessment, 3, 182-187. doi: $\underline{10.1037 / 1040-3590.3 .2 .182}$

Driscoll, M. P. (2005). The psychology of learning for instruction ( $3^{\text {rd }}$ Edition). Boston, MA: Pearson.

Elliot, A. J. (1999). Approach and avoidance motivation and achievement goals. Educational psychologist, 34(3), 169-189. doi: 10.1207/s15326985ep3403_3

Elliot, A.J., \& Church, M.A. (1997). A hierarchical model of approach and avoidance achievement motivation. Journal of Personality and Social Psychology, 72(1), 218-232. doi: 10.1037/0022-3514.72.1.218

Elliot, A.J., \& McGregor, H.A. (2001). A 2x2 achievement goal framework. Journal of Personality and Social Psychology, 80, 501-519. doi: 10.1037/0022-3514.80.3.501

Elliot, A.J., \& Reis, H.T. (2003). Attachment and exploration in adulthood. Journal of Personality and Social Psychology, 85, 317-331. doi: 10.1037/0022-3514.85.2.317

Fraenkel, J.R., \& Wallen, N.E. (2000). How to design and evaluate research in education (4 ${ }^{\text {th }}$ ed). Boston. McGraw Hill.

Garver, M. S., \& Mentzer, J.T. (1999). Logistics research methods: Employing structural equation modeling to test for construct validity. Journal of Business Logistics, 20(1), 33-57.

Holden, R. R., Fekken, G. C., \& Cotton, D. H. G. (1991). Assessing psychopathology using structured test item response latencies. Psychological Assessment, 3, 111-118. doi: 10.1037/1040-3590.3.1.111

Kuzgun, Y. ve Deryakulu, D. (2004). Bireysel farklılıklar ve eğitime yansımaları. Y. Kuzgun (Ed.) ve D. Deryakulu (Ed.), Ĕ̆itimde bireysel farklılıklar (s.95-136). Ankara: Nobel Yayın Dağıtım.

McCoach, D. B., \& Siegle, D. (2003). Factors that differentiate underachieving gifted students from high achieving gifted students. Gifted Child Quarterly, 47, $144-154$.

Nunnally, J. (1978). Psychometric theory. New York: McGraw-Hill.

O’Rourke, N., Hatcher, L., \& Stepanski E. J. (2005). A Step-by-Step Approach to Using SAS for Univariate and Multivariate Statistics (Second Edition). Cary, NC: SAS Institute Inc.

Özbay, A. (2008). Yabancı dilde bilgilendirici yazma alanında öz düzenleme becerilerinin kullanımı ve başarı arasındaki ilişki. Yayımlanmamış Doktora Tezi, Hacettepe Üniversitesi, Ankara, Türkiye. Retrieved from https://tez.yok.gov.tr/UlusalTezMerkezi/

Özturan Sağırlı, M., Çiltaş, A., Azapağası, E. ve Zehir, K. (2010). Yükseköğretimin öz-düzenlemeyi öğrenme becerilerine etkisi (Atatürk Üniversitesi örneği). Kastamonu Ĕgitim Dergisi, 18(2), 587-596.

Pamuk, S. (2014). Multilevel analysis of students science achievement in relation to constructivist learning environment perceptions, epistemological beliefs, self-regulation and science teachers characteristics. Unpublished doctoral dissertation. Middle East Technical University, Ankara, Turkey. Retrieved from http://etd.lib.metu.edu.tr/upload/12617892/index.pdf

Pintrich, P. R. (1999). The role of motivation in promoting and sustaining self-regulated learning. International Journal of Educational Research, 31(6), 459-470. doi: 10.1016/S0883-0355(99)00015-4

Pintrich, P. R. (2000a). The role of goal orientation in self-regulated learning. In M., Boekaerts \& P. R., Pintrich (Eds.), Handbook of self-regulation (pp.13-39). San Diego, CA: Academic Press.

Pintrich, P. R. (2000b). Multiple goals, multiple pathways: The role of goal orientation in learning and achievement. Journal of Educational Psychology, 92,544-555. doi: 10.1037/0022-0663.92.3.544 
Pintrich, P. R., \& De Groot, E. V. (1990). Motivational and self-regulated learning components of classroom academic performance. Journal of Educational Psychology, 82(1), 33-40. doi: 10.1037/0022$\underline{0663.82 .1 .33}$

Pintrich, P. R., Smith, D. A. F., Garcia, T. \& McKeachie, W. J. (1991). A manual for the use of the motivated strategies for learning questionnaire (MSLQ). National Center for Research to Improve Postsecondary Teaching and Learning. Ann Arbor: Michigan. ED 338 122. Retrieved from https://files.eric.ed.gov/fulltext/ED338122.pdf

Pintrich, P. R., Smith, D. A. F., Garcia, T., \& McKeachie, W. J. (1993). Reliability and Predictive Validity of the Motivated Strategies for Learning Questionnaire (MSLQ). Educational and Psychological Measurement, 53(3), 801-813.doi: 10.1177/0013164493053003024

Sakız, G. ve Yetkin Özdemir, İ. E. (2014). Özdüzenleme ve özdüzenlemeli öğrenme: Kuramsal bakış. G. Sakız (Ed.), Özdüzenleme (s. 29-47). Ankara: Nobel Akademik Yayıncılık.

Sarı, A. ve Akınoğlu, O. (2009). Öz-düzenlemeli öğrenme: Modeller ve uygulamalar. M.Ü. Atatürk Ĕgitim Fakültesi Ĕ̆itim Bilimleri Dergisi, 29, 139-154.

Schermelleh-Engel, K., Moosbrugger, H., \& Müller, H. (2003). Evaluating the fit of structural equation models: Tests of significance and descriptive goodness-of-fit measures. Methods of Psychological ResearchOnline, 8 (2), 23-74.

Senemoğlu, N. (2011). Gelişim, ögrrenme ve ögrretim (20. Bask1). Ankara: Pegem Akademi.

Sungur, S. (2004). An implementation of problem based learning in high school biology courses. Unpublished Dissertation, Middle East Technical University, Ankara, Turkey. Retrieved from https://tez.yok.gov.tr/UlusalTezMerkezi/

Şen, Ş. (2015). Investigation of Students' Conceptual Understanding of Electrochemistry and Self-Regulated Learning Skills in Process Oriented Guided Inquiry Learning Environment. Unpublished Dissertation, Hacettepe University, Ankara, Turkey. Retrieved from https://tez.yok.gov.tr/UlusalTezMerkezi/

Şenler, B. (2011). Pre-service science teachers 'self-efficacy in relation to personality traits and academic selfregulation. Unpublished Dissertation, Middle East Technical University, Ankara, Türkiye. Retrieved from https://tez.yok.gov.tr/UlusalTezMerkezi/

Şenler, B., \& Sungur, S. (2007). Hedef yönelimi anketinin Türkçe 'ye çevrilmesi ve adaptasyonu. 1. Ulusal Ilköğretim Kongresi, Ankara.

Taştan, O. (2009). Effect of cooperative learning based on conceptual change conditions on motivation and understanding of reaction rate. Unpublished Dissertation, Middle East Technical University, Ankara, Türkiye. Retrieved from https://tez.yok.gov.tr/UlusalTezMerkezi/

Yalçınkaya, E. (2010). Effect of case based learning on 10th grade students' understanding of gas concepts, their attitude and motivation. Unpublished Dissertation, Middle East Technical University, Ankara, Türkiye. Retrieved from http://etd.lib.metu.edu.tr/upload/3/12611523/index.pdf

Yumuşak, N., Sungur, S., \& Çakıroğlu, J. (2007). Turkish high school students' biology achievement in relation to academic self-regulation. Educational Research and Evaluation, 13(1), 53 - 69. doi: $\underline{10.1080 / 13803610600853749}$

Zimmerman, B. J. (1989). A social cognitive view of self-regulated academic learning. Journal of Educational Psychology, 81(3), 329-339. doi:10.1037/0022-0663.81.3.329

Zimmerman, B. J. (2000). Attaining Self-Regulation: A Social Cognitive Perspective. In M. Boekaerts, P. Pintrich, \& M. Zeidner (Eds.), Self-Regulation: Theory, Research, and Applications (13-39). San Diego, CA: Academic Press.

Zimmerman, B. J. (2002). Becoming a self-regulated learner: An overview. Theory into practice, 41(2), 64-70. Retrieved from https://www.jstor.org/stable/1477457

Zinbarg, R. E., Revelle, W., Yovel, I. \& Li, W. (2005). Cronbach's $\alpha$, Revelle's, $\beta$ and McDonalds $\omega$ : Their relations with each other and two alternative conceptualizations of reliability. Psychometrika, 70(1), 111. doi: 10.1007/s11336-003-0974-7

\section{Öz-düzenleyici Öğrenme Becerileri: Ölçek Uyarlama}

\section{Giriş}

Öz-düzenleme, bireylerin davranışlarını gözlemlemesi ve kendi ölçütleriyle karşılaştırmalar yaparak yargıda bulunması ve gerektiğinde davranışlarını kendi ölçütlerine göre yeniden düzenlemesidir. Özdüzenleyici bireyler kendi davranışlarını etkilerler, yönlendirirler ve kontrol ederler (Bandura; aktaran, Senemoğlu, 2011). Zimmerman (2000)'a göre öz-düzenleme, bireylerin bireysel hedeflerine ulaşmak

ISSN: 1309 - 6575 Eğitimde ve Psikolojide Ölçme ve Değerlendirme Dergisi Journal of Measurement and Evaluation in Education and Psychology 
adına geliştirdikleri, planlı ve döngüsel olarak ortaya çıkan düşünceler, duygular ve davranışlardır. Sosyal bilişsel kurama göre öz-düzenleme, sosyal ortamda gelişir ve zamanla bireyler tarafindan içselleştirilir. Bu kurama göre öz-düzenlemenin yapısında bilişsel, metabilişsel ve motivasyonel bileşenler bulunmaktadır (Zimmerman; aktaran, Sakız \& Yetkin Özdemir, 2014). Bundan dolayı özdüzenleyici öğrenciler öğrenme sürecinde metabilişsel, motivasyonel ve davranışsal olarak etkin bir rol alırlar, kendi öğrenme hedeflerini oluştururlar ve bu süreci kontrol ederler (Zimmerman, 1989). Bu tanımlara göre, öz-düzenleme zihinsel bir beceri ya da akademik bir yetenek olarak tanımlanmayıp, öğrenenin sahip olduğu bilişsel yeterliklerini akademik yetenekler şeklinde adapte ettiği ve bunu da kendisi tarafindan yönettiği bir süreç olarak özetlenebilir (Zimmerman, 2002).

Sosyal bilişsel kurama dayalı öz-düzenleme modellerinin ortaya çıkmasıyla, bağlamın öz-düzenleme süreçlerindeki öneminin göz ardı edilemeyeceği fikri ortaya çıkmıştır. Bağlam (kontekst); bir durum, bir fikir veya bir olay için çevreyi oluşturan koşullar şeklinde tanımlanabilir ("Context", 2018). Bağlamın, bulguların geçerliliğini etkileyebileceği fikrinin ortaya çıkması ile yapılan ölçümler bağlama duyarlı hale getirilmiştir. Böylece farklı öğrenme alanlarına yönelik ölçümler giderek daha fazla önem kazanmıştır (Pintrich; aktaran, Özbay,2008). Kısacası, durumlar arası genellemelere dayalı ölçümler yerine bağlama duyarlı, özel öğrenme alanlarına ve görevlerine yönelik ölçümler daha fazla önem kazanmıştır. Literatürde yapılan çalışmalar arasında sosyal bilişsel kurama dayalı olarak Pintrich vd. (1991) tarafından geliştirilen "Öğrenmede Güdüsel Stratejiler Ölçeği” (ÖGSÖ) sıklıkla kullanılmaktadır. Pintrich vd. (1991) ölçekte üniversite öğrencilerine yönelik bir dersi analiz birimi olarak belirlemişlerdir (Özbay, 2008). ÖGSÖ, motivasyon ve öğrenme stratejilerinin kullanımında bağlamın önemli bir etkisinin olduğu, farklı ögrenme alanlarında ve görevlerinde farklı stratejilerinin kullanımının gerektiği görüşüne dayalı olarak geliştirilmiştir (Özbay, 2008). ÖGSÖ, öğrencilerin bilişsel düzenleme göstergeleri olarak beş alt boyut içerir. $\mathrm{Bu}$ alt boyutlar; yineleme, açımlama, düzenleme, eleştirel düşünme ve metabilişsel özdüzenleme boyutlarıdır. Pintrich (2000a) tarafından önerilen öz-düzenleyici öğrenme modeli çerçevesinde bazı biliş kontrol aktiviteleri ve izleme ölçümleri ile Zimmerman (2000) tarafindan önerilen model çerçevesinde bazı performans kontrol aktivitelerinin yer aldığı alt boyutlar vardır. Motivasyonun ve duyuların düzenlenmesi ile ilgili olarak ÖGSÖ motivasyonel stratejilerin ölçülmesine yönelik alt boyutlar içermemektedir. Fakat performans ve öğrenme hedefleri olmak üzere başarı hedefleri (achievement goals), görev değeri, öğrenme ve performansla ilişkili öz-yeterlik ve sınav kaygısı Zimmermann'ın modelinde yer alan önsezi aşamasında vurgulanan öğrencilerin motivasyonel inançlarının yer aldığı alt boyutlar bulunmaktadır. Davranışın düzenlenmesi ile ilgili olarak ise ÖGSÖ'da üç alt boyut mevcuttur. Bunlar; öğrencilerin zor ve ilgi çekmeyen görevlerle karşılaştıklarında kendi çabalarını düzenlemeleri, zaman ve çalışma ortamı yönetimi ve yardım almak için birini belirlemeye yönelik alt boyutlardır. Aslında hem Zimmerman hem de Pintrich tarafından geliştirilen ve sosyal bilişsel teoriye dayalı olan öz-düzenleyici öğrenme modellerinde performans kontrolü, zaman yönetimi, yardım arama ve çevresel yapılandırma gibi öz-düzenleyici stratejilerin vurgusu yapılmaktadır. Son olarak ÖGSÖ bağlamın düzenlenmesi ile ilişkili iki alt boyut daha içermektedir. Bu alt boyutlar akran öğrenimi ile zaman ve çalışma ortamı yönetimidir. $\mathrm{Bu}$ alt boyutlar öğrencilerin öğrenme kaynăğ olarak arkadaşlarını ne kadar iyi kullandıklarını ve çalışma ortamı ile zamanlarını ne kadar iyi yönettiklerini belirlemek için kullanılır (Yumuşak, Sungur \& Çakıroğlu, 2007).

Bağlamın, bulguların geçerliliğini etkilemesinden dolayı bağlama duyarlı ölçümlerin yapılması ihtiyacı ortaya çıkmaktadır. Bu sebeple farklı öğrenme alanlarına yönelik ölçümler giderek daha fazla önem kazanmıştır (Pintrich; aktaran, Özbay, 2008). Fakat yapılan çalışmalarda lise öğrencilerinin farklı derslerdeki öz-düzenleyici öğrenme becerilerinin belirlenmesi için geçerli ve güvenilir ölçeklerin olmadığı belirlenmiştir. Bundan dolayı öğrencilerin kimya dersindeki öz-düzenleyici öğrenme becerilerini geliştirmek için öncelikle değerlendirmede kullanılacak ölçeklere ihtiyaç duyulmaktadır. Ayrıca alanyazında kullanılan ÖGSÖ'da yer alan başarı hedeflerinin iki genel başarı hedefleri şeklinde sınırlandırılmış olması Öğrenmede Güdüsel Stratejiler Ölçeği ve Hedef Yönelimi Ölçeklerinin birlikte kullanımı gerekliliğini ortaya çıkarmıştır. Bundan dolayı bu iki ölçeğin uyarlanarak geçerlik ve güvenirlik çalışmaları yapılmalıdır. Bu doğrultuda, bu çalışmada; lise öğrencilerinin öz-düzenleyici öğrenme becerilerini belirlemek için ÖGSÖ ve HYÖ kimya dersi için uyarlanmış ve psikometrik özellikleri incelenmiştir. 


\section{Yöntem}

Çalışmaya 9., 10., 11., ve 12. sınıflara devam etmekte olan toplam 862 lise öğrencisi katılmıştır. Öğrencilerin \%35.03'ü k1z, \%33.06's1 erkek öğrencilerden ve \%31.9'u da herhangi bir kodlama yapmamıştır. Öğrencilerin, yaşları 16-20 arasında değişmektedir.

Veri Toplama aracı olarak HYÖ ve ÖGSÖ ölçekleri kullanılmıştır. Elliot ve McGregor (2001) tarafindan üniversite öğrencileri için geliştirilmiş olan Hedef Yönelimi Ölçeği (HYÖ) Şenler ve Sungur (2007) tarafından Türkçeye adaptasyonu yapılmıştır. Şenler ve Sungur tarafından ölçek fen dersleri için uyarlanmış olup ilköğretim öğrencilerine uygulanmıştır. 7'li likert tipi olan ölçek araştırmacılar tarafından 5'li likert şeklinde uyarlanmıştır. Bu çalışmada ise, ölçek orijinal versiyonunda olduğu gibi 7'li likert şeklinde ve lise öğrencilerine yönelik kimya dersleri için izin alınarak uyarlanmıştır. ÖGSÖ, Pintrich, Smith, Garcia ve McKeachie (1991) tarafından üniversite öğrencilerinin derslerdeki motivasyonları ve bu derslerde kullandıkları öğrenme stratejileri hakkında bilgi elde etmek için geliştirilmiştir. Ölçek, Büyüköztürk, Akgün, Özkahveci ve Demirel (2004) ve Sungur (2004) tarafından Türkçe'ye uyarlanmıştır. 7'li Likert tipi bir ölçektir. ÖGSÖ'nın motivasyon ve öğrenme stratejileri olmak üzere iki ana bileşeni bulunmaktadır.

Ölçeklerde yer alan alt boyutların yapı geçerliği için doğrulayıcı faktör analizi yapılarak analiz edilmiştir. Ölçeklere ilişkin güvenirlik değerlerini elde etmek için ise bir iç tutarlılık katsayısı olan Cronbach Alfa değerlerinin yanı sıra McDonalds'ın Omega $(\omega)$ katsayısı hesaplanmıştır. Ayrıca ölçeklerde yer alan her bir maddenin güvenirliği için madde toplam korelasyon değerleri incelenmiştir.

\section{Sonuç ve Tartışma}

Öğrencilerin sahip oldukları bireysel farklılıklar, öğretme-öğrenme sürecinde dikkate alınması gereken önemli özelliklerdir. Çünkü öğrencilerin tercih ettikleri öğretme-öğrenme yaklaşımları, ögretim uygulamalarına verdikleri tepkiler sahip oldukları bu bireysel özelliklerindeki farklılıklara göre değişmektedir. Bu bireysel özellikler, bilişsel, duyuşsal, toplumsal ve fizyolojik kategoriler altında sınıflandırılabilir. Farklı motivasyon düzeylerine sahip olmak, algısal tercihlerdeki farklılıklar, zeka düzeyi ve psikolojik faktörler gibi bireysel farkl1lıklar olarak tanımlanabilecek bir çok faktör bireylerin öğretme-öğrenme süreçlerini etkiler (Kuzgun \& Deryakulu, 2004). Bu bireysel farklılıklardan bir tanesi de öğrencilerin öz-düzenleyici öğrenme becerileridir. Dolayısıyla öğrencilerin öğretme-öğrenme ortamlarındaki öz-düzenleyici öğrenme becerilerini belirlemek için geçerli ve güvenilir ölçeklere ihtiyaç duyulmaktadır. Sosyal bilişsel kurama dayalı öz-düzenleme modellerinin ortaya çıkmasıyla, bağlamın öz-düzenleme süreçlerindeki öneminin göz ardı edilemeyeceği fikrinin ortaya çıkması farklı derslerde kullanılacak olan ölçeklere gereksinim duyulmaktadır. Bu sebeple bu çalışmada lise öğrencilerinin öz-düzenleyici öğrenme becerilerinin ölçülmesi amacıyla Hedef Yönelimi Ölçeği ile birlikte Öğrenmede Güdüsel Stratejiler Ölçeği kimya dersi için uyarlanarak psikometrik özellikleri incelenmiştir. Ölçeklerde yer alan alt boyutların yap1 geçerliği için doğrulayıcı faktör analizi yapılarak analiz edilmiştir. Ölçeklere ilişkin güvenirlik değerlerini elde etmek için ise bir iç tutarlılık katsayısı olan Cronbach Alfa değerlerinin yanı sıra McDonalds'ın Omega $(\omega)$ katsayısı hesaplanmıştır. Ayrıca ölçeklerde yer alan her bir maddenin güvenirliği için madde toplam korelasyon değerleri incelenmiştir.

Hedef Yönelimi Ölçeği için yapılan doğrulayıcı faktör analizi sonuçları incelendiğinde; ölçeğe ait uyum değerleri $\mathrm{RMSEA}=.07$; $\mathrm{GFI}=.94 ; \mathrm{NFI}=.97$; $\mathrm{AGFI}=.91, \mathrm{NNFI}=.97 ; \mathrm{CFI}=.98$ ve $\mathrm{SRMR}=.042$ şeklindedir. Çalışmada öğrenme yaklaşma boyutu için tespit edilen Cronbach Alfa $(\alpha)$ değeri .85, ögrenme kaçınma boyutu için .79; performans yaklaşma boyutu için .77 ve performans kaçınma boyutu için ise bu değer 67 olarak hesaplanmıştır. Ölçeğe ait sonuçlar incelendiğinde özdüzenleyici öğrenme becerilerinin bir bileşeni olan başarı hedeflerinin daha detaylı bir şekilde bu ölçekle ölçülebileceği söylenebilir (Şen, 2015).

Öğrenmede Güdüsel Stratejiler Ölçeğinin (ÖGSÖ) motivasyon boyutuna ait uyum değerleri (fit indices) ise $\mathrm{RMSEA}=.07 ; \mathrm{GFI}=.89 ; \mathrm{NFI}=.97 ; \mathrm{AGFI}=.87, \mathrm{NNFI}=.97 ; \mathrm{CFI}=.97$ ve $\mathrm{SRMR}=.044$ 
şeklindedir. Çalışmada Görev Değeri boyutu için hesaplanan Cronbach Alfa $(\alpha)$ değeri .85, Öğrenmeye İlişkin Kontrol İnancı boyutu için .73; Öğrenme ve Performansla ilgili Özyeterlik boyutu için .87 ve Sınav Kaygısı boyutu için ise bu değer .61 olarak hesaplanmıştır. Ölçeğin öğrenme stratejileri boyutu için hesaplanan uyum değerleri; RMSEA $=.059$; NFI $=.94$; GFI $=.83$; NNFI $=.95$; AGFI=.81, CFI $=.95$ ve SRMR = .079 şeklindedir. Çalışmada yineleme boyutu için belirlenen Cronbach Alfa $(\alpha)$ değeri .76, düzenleme boyutu için .68, açımlama boyutu için .78, eleştirel düşünme boyutu için .76, metabilişsel özdüzenleme boyutu için .84, zaman ve çalışma alanı yönetimi boyutu için .75 , çaba yönetimi boyutu için .69, akran öğrenimi boyutu için .71, yardım arama boyutu için .59 olarak hesaplanmıştır (Şen,2015). Ölçeklere ait tüm değerler göz önünde bulundurulduğu zaman ölçeklerin geçerlik ve güvenirlik açısından psikometrik özellikleri karşıladığına karar verilmiştir. Sonuç olarak geçerlik ile güvenirliği sağlanmış olan her iki ölçek, eğitimcilerin öz-düzenleyici öğrenme becerilerini belirleme amacına hizmet edebilecek ölçekler olarak literatüre katkı sağlayabilir. Ayrıca eğitimciler ölçeklerde yer alan her bir alt boyutu ayrı ayrı olarak da kullanarak sonuçları inceleyebilirler. 